\title{
Chapter 3: Advocacy journalism, the politics of humanitarian intervention and the Syrian war
}

\author{
Philip Hammond, Sumaya Al Nahed and Tara McCormack
}

Since 2011 the international media have done much to highlight the suffering of civilians in the on-going war in Syria, including through innovative forms of reporting such as VR journalism and news games. ${ }^{1}$ Yet in some respects coverage has harked back to an earlier era, recalling the style of 'attached' or advocacy journalism that developed in the 1990s. As in much Western reporting of the wars of that period, some journalists have understood the conflict in simplified, black-and-white terms and called for 'something to be done' to counter an evil regime and rescue innocent victims. Such coverage - like Western policy itself - has only occasionally involved direct and overt military interventionism (Briggs et al. 2017: 167). Yet a subtler but no less significant use of "emotive phrases...such as, "History will judge us"..."We cannot look the other way"...and "What will the world think"' has beaten a steady drum for escalating international involvement in the conflict (Milojevich and Beattie 2018: 831-2).

This narcissistic approach, characteristic of 1990s-style advocacy journalism (Hume 1997), has led many to interpret the Syrian war as a test for Western selfunderstanding. In the Telegraph (24 August 2013), for example, Matthew d'Ancona said that the 'Syrian conflict holds a mirror up to Britain and asks us what sort of nation we want to be'; while the BBC's Gavin Hewitt interpreted it as a 'test for Europe' (BBC, 27 August 2013). In its editorial columns, the Guardian depicted the battle for Aleppo as 'a rebuke to America and the world' (10 February 2016), where 'the credibility of western strategies' was 'hang[ing] in the balance' (3 August), and as 'a humiliation for the UN' (30 November). Columnist Natalie Nougayrède described the conflict as 'a moral defeat for Europeans', affecting 'how we relate to the world, to ourselves and to the values we like to profess' (Guardian, 27 February 2018). Times columnist Philip Collins acknowledged that 'Intervention... will mean chaos', but shrugged this off: 'there is chaos already', he argued, and it was 'important to add weight to our moral impulse' (Times, 24 February 2012).

For Collins - formerly a speechwriter for Tony Blair - the problem was that the 'idea of liberal intervention...fell apart in Iraq'. Syria, he maintained, was the 'counterfactual for Iraq', showing 'what Iraq would have been like, sooner or later' and thereby providing a retrospective justification for the 2003 invasion. Jonathan Freedland pursued a similar line in the Guardian (10 February 2012): Iraq had 'tainted for a generation the idea once known as "liberal interventionism"', he said, but this made 'no moral sense'. Initially, it perhaps seemed possible to rehabilitate this idea: Freedland had made a similar, but more optimistic argument about Libya, where, he maintained, 'the case for intervention remains strong' (Guardian, 22 March 2011); and Collins hoped that the 'success of our intervention in Libya...is redeeming the argument that was lost in Iraq' (Times, 24 February 2012). In August 2013, the parliamentary defeat of British government proposals for airstrikes in Syria, and President Barack Obama's reversal of his earlier decision to take direct action if the 'red line' of chemical weapons use was crossed, put full-blown Western military intervention off the immediate agenda - although the US and its allies carried out air strikes in 2017 and 2018. As the 'successful' Libyan intervention also fell apart in bloodshed and chaos, the prospect of rehabilitating liberal interventionism in Syria receded even further. 
Committed commentators did not react well to the 'tainting' of the idea of liberal interventionism. Freedland despaired that 'public opinion seems utterly disengaged, unbothered by the slaughter', and inveighed against the 'complicity' and 'indifference' of 'both the public and anti-war left' (Guardian, 19 October 2012, 21 February 2018). Similarly, in the Independent Kate Maltby accused her readers: 'If you say "something must be done" about Aleppo but opposed David Cameron when he tried to act, you have blood on your hands' (14 December 2016). Articulating a common theme of such commentary, Maltby particularly denounced the 'denialists' and 'twitter bots' who questioned official claims about the war, accusing those who 'willingly consumed such propaganda' of guilt by association with the 'Assadist-Putinist war machine'. As the attempt to establish a clear moral framework of an evil regime massacring innocent civilians became increasingly frustrated - by the complexities of the conflict itself and by the many sceptical and critical responses circulating freely online - there was an attempt to close down debate by denouncing anti-war critics.

This chapter analyses those efforts to shore up the mainstream narrative and delegitimise dissent. To begin, however, it is important to place this in context. The echoes of 1990s-style advocacy journalism highlighted above are not surprising since, as critics have noted, the Bosnian war has repeatedly been invoked as a precedent to bolster calls for intervention in Syria and elsewhere (Gibbs 2015). When journalists looked at Syria and saw 'another Srebrenica' (Guardian, 20 February 2018), they cast themselves as critics of a Western policy which they understood to be far too uninvolved and non-interventionist. Yet as in Bosnia (Chandler 2000), Western political, financial and military interventions have, from the outset, escalated conflict. As Patrick Higgins (2015) notes, in commentary on Syria 'the demand to "do something" sidesteps what has already been done - there is a foundational assumption that the ruin and bloodshed of this terrible war have been produced by inaction'.

\section{The myth of Western inaction}

Beginning in 2011 in the context of protests in several Arab states, the Syrian uprising rapidly became an internationalised, multi-sided civil war. From the start, America, Britain and other European governments explicitly argued that President Bashar al-Assad could not remain in power, inevitably emboldening the rebels. By summer 2011, an 'activist' in Damascus was telling the Washington Post: 'It was as if someone told us, "We have your back"...we've entered a new phase now because what the US has done is tell [Assad] there's no way out now except to fight' (19 August 2011). Western governments were soon not only stripping the Syrian government of legitimacy but also backing those they thought should overthrow and replace it. As the Washington Post reported in 2016, the 'centerpiece of the US strategy to press [Assad] to step aside' was a 'covert CIA program that has trained and armed thousands of Syrian fighters' (23 October 2016). By this point, the strategy was seen by some insiders as having fallen apart - the Post article quoted a 'senior US official' wondering 'whether agency-supported fighters can still be considered moderate, and whether the program can accomplish anything beyond adding to the carnage in Syria' - and the CIA programme was reportedly ended in 2017. Yet it is questionable whether the public claims - that the US and its allies were only helping 'moderate' groups, which had been 'vetted' to exclude extremists were ever accurate (Gambill 2012). A more realistic assessment of US policy was offered by Jeffrey Sachs: 'We started a war to overthrow a regime...a major war effort, shrouded in secrecy, never debated by Congress, never explained to the American people....And this created chaos. ${ }^{2}$ 
The ostensible beneficiary of Western support has been the Free Syrian Army (FSA), initially established in 2011 by Syrian Army defectors, possibly with Turkish intelligence support (Lund 2013). The name, however, was loosely applied to numerous groups, including many radical Islamist factions. By 2012, as a 'cascade' of US politicians advocated arming the rebels, the FSA remained 'something of a fiction, a convenient mailbox for a diverse, unorganized collection of local fighting groups' (Lynch 2012), ranging from the original Syrian Army defectors to militant jihadis. Colonel Abdel Jabbar al-Okaidi, described as one of the 'most senior Syrian rebel commanders to be backed by Britain and the United States' (Telegraph, 4 November 2013), gave interviews in which he spoke warmly of the constructive and cooperative relationship between the FSA and Islamic State (ISIS), and defended the record of FSA ally and al-Qaeda affiliate Jabhat al-Nusra. ${ }^{3}$ Other groups fighting under the FSA banner and in receipt of 'financial and arms support from the US' included Nour al-Din al-Zinki, who infamously videoed themselves beheading a child (Los Angeles Times, 20 July 2016). In 2015 Charles Lister described a successful offensive, planned and executed over several months, which involved 'moderate and conservative Syrian Islamists...al Qaeda affiliate Jabhat al-Nusra and several independent jihadist factions' alongside the FSA. A 'US-led operations room in southern Turkey' had been 'instrumental in facilitating [the] involvement' of the various factions, and had 'specifically encouraged a closer cooperation with Islamists commanding frontline operations' (Lister 2015).

Given this record of cooperation, it seems reasonable to conclude that there was a concerted international effort by America and its allies, involving many millions of dollars, to overthrow Assad by deliberately funding and arming radical Islamist terror groups. Even on the most charitably uncritical interpretation one would have to suppose that in their pursuit of regime change in Syria, foreign powers were extraordinarily careless in funnelling money and weapons into the war zone, with, if not little regard, then certainly little control over where these ended up. An investigation by the BBC's Panorama programme revealed how British funding for the 'Free Syrian Police' had ended up 'funding jihadis'. This was not a deliberate policy, but both the UK government and the private contractor delivering the project apparently turned a blind eye to fraud and corruption. Most tellingly, witnesses said it was virtually impossible to operate without paying and cooperating with groups such as al-Zinki and al-Nusra, who were the de facto civil authorities in their respective areas of control. ${ }^{4}$ In 2012 the New York Times was already reporting that most of the arms supplied to Syrian rebel groups were 'going to hard-line Islamic jihadists' (14 October 2012). By mid-2015, the goal of the CIA's mission in Syria - now 'one the agency's largest covert operations, with a budget approaching $\$ 1$ billion' - had reportedly 'shifted from ousting Assad to countering the rise of extremist groups including al-Qaeda affiliated Jabhat al-Nusra and the Islamic State' (Washington Post, 12 June 2015). The fact that a few months later, as noted above, Lister was writing of successful cooperation with al-Nusra coordinated by the CIA makes this seem rather implausible. Either way, a billion-dollar mission can hardly be described as inaction.

Yet at the end of 2015 commentators were still maintaining that, in contrast to Russian support for the Syrian government, 'Washington's support to the opposition is more the stuff of jokes than anything serious' (Matta 2015). As for Islamic State, a study by Conflict Armament Research $(2017: 8,121)$ concluded that 'international weapon supplies to factions in the Syrian conflict have significantly augmented the quantity and quality of weapons available to IS forces', including materials to manufacture 'rudimentary chemical projectiles'. The report noted that such 'adverse effects associated with international intervention in civil wars' were 'not new': Western support for the Mujahedeen in Afghanistan in the 1980s had 'displayed 
similar patterns' (2017: 146). A further parallel with the '80s, of course, was that a local war became a proxy for conflict between the US and Russia. By mid-2015 ISIS reportedly controlled half of Syrian territory (Guardian, 21 May 2015), but the Syrian government asked Russia for military support and the ensuing Russian bombing campaign helped to push ISIS back, turning the war in Assad's favour. Russian military intervention effectively confounded Western hopes of regime change in Syria. In addition, if Western policy was intended to counter the regional influence of Assad's other key ally, Iran, it probably had the opposite effect: making the conflict a matter of the regime's survival also made its relationship with Iran closer and more significant (Glass 2015).

Russia's intervention was one of the key factors highlighted by Philip Gordon, former White House Coordinator for the Middle East, in arguing that US policy 'must be rethought'. He noted ruefully that:

Editorials in the Washington Post and elsewhere blame US 'inaction' for the tragedy in Syria while calling for 'robust intervention' and 'more aggressive US effort to bring down' the Assad regime. Former US officials... denounce 'piecemeal' US efforts to support the opposition and call on the United States to sharply ramp up those efforts to help bring down Assad. Many pundits and columnists seem to share...[the] conclusion that Washington's unwillingness to act 'decisively' is proof that 'the United States has abandoned its faith in its power and its duty to do good'.

(Gordon 2015)

The logic of such arguments, Gordon observed, was to push for an escalation to fullscale military action. Rejecting this as dangerous and unpredictable, he nevertheless acknowledged that the 'current policy' of the US and its allies - to 'train and equip a moderate, unified opposition capable of pressuring the Assad regime to change' had failed. Following Daniel Hallin, we would expect to see this breakdown of elite consensus on Western policy reflected in media coverage. Advocacy journalists, however, responded by seeking to police the boundaries of 'legitimate controversy' (Hallin 1986: 110).

\section{Losing control of the narrative}

Frustration at criticism of the official narrative about Syria came to a head at the end of 2017, in the context of a wider panic about 'fake news' and Russian attempts to manipulate US elections via social media (Chen 2018). The Guardian (Solon 2017) said it had 'uncovered how [a] counter-narrative [about Syria] is propagated online by a network of anti-imperialist activists, conspiracy theorists and trolls with the support of the Russian government (which provides military support to the Syrian regime)'. This framing was plainly designed to delegitimise any 'counter-narrative' by linking it to 'conspiracy theorists' (mentioned six times in the article), internet trolls and bots (five mentions), and especially to Russia (mentioned 23 times). The author, technology journalist Olivia Solon, interviewed academics and other specialists to depict a systematic and coordinated effort at deception by a hidden network operating an 'online propaganda machine' or 'a factory'.

Solon's tone of sensational revelation was clearly added for dramatic effect, since much of what was 'uncovered' was not particularly novel. Kate Starbird from the University of Washington was quoted for her research on Twitter from three months earlier. Scott Lucas from Birmingham University was quoted explaining how "propagandists are able to create a "manufactured consensus" that gives legitimacy 
to fringe views', but he had been airing such opinions for over a year, as had another interviewee, Eliot Higgins, introduced as the 'founder of the investigative reporting collective Bellingcat'. ${ }^{5}$ One new source was Graphika, which describes itself as a 'social media intelligence firm'. After apparently spending 'years analysing a range of Russian disinformation campaigns' the company was commissioned by the Syria Campaign, described by Solon as a 'human rights group'. Presumably not coincidentally, the Syria Campaign published its own report two days later, under the title 'Killing the Truth: How Russia is fuelling a disinformation campaign to cover up war crimes in Syria'. Solon had essentially pre-released the report's findings with supporting quotes from sympathetic experts.

The Syria Campaign's (2017: 40) report underscored the rationale for the accompanying Guardian exposé: that awkward questions (or 'conspiracy theories') about official accounts of the war were now 'seeping into mainstream discourse with very little scrutiny'. Two women who had reported independently from Syria - Eva Bartlett and Vanessa Beeley - attracted particular opprobrium. Solon quoted the Syria Campaign's director, James Sadri, saying that Beeley 'should not be taken seriously' since she was a 'key player' in the Russian government's 'propaganda campaign'. The Syria Campaign (2017: 22) report in turn described her as the 'queen of disinformation', placing her 'at the heart of this Russian-backed disinformation campaign'. The aim was evidently to police the boundaries of acceptable opinion: the Syria Campaign (2017: 5) offered recommendations to technology companies, social media users, governments and news organisations, advising the latter: 'Be careful who you recognise as journalists. It can be used as a label to legitimise propagandists'.

The Syria Campaign report offered only one example of 'fringe views' entering the mainstream: the work of US journalist Max Blumenthal on AlterNet. Yet perhaps this was at least partly a response to the fact that (as discussed below) Blumenthal had written critically about the Syria Campaign itself. The Graphika research showed that of all the suspect Twitter accounts identified, the one with the 'greatest reach and influence' was that of Lebanese woman Sarah Abdallah (Syria Campaign 2017: 33). The accusations against Abdallah were that she 'posts a large amount of proRussian content'; she has many Twitter followers; and some these followers are influential people, including journalists (whose names they published online). These things are true, but constitute an absurd charge-sheet. Abdallah does post much proRussian content, including topless photos of Vladimir Putin, but unless admiring Russia is itself a thoughtcrime it is difficult to see the problem. She does have many Twitter followers - but less than a third of the number attracted by eight-year-old Bana Alabed, whose tweets from rebel-held Aleppo were eagerly tracked by the international media (New York Times, 7 December 2016). The journalists following Abdallah seem to give her far less attention than they did the bogus 'Gay Girl in Damascus' account - written by 40-year-old American Tom MacMaster - which 'gained a worldwide readership and was closely followed by news organisations'. ${ }^{6}$ The Syria Campaign (2017: 33) found it 'remarkable that this individual with no professional background has emerged as such [an] influential commentator in this debate' - but the same could be said of Rami Abdulrahman, who runs the 'Syrian Observatory for Human Rights' from his home in Coventry (New York Times, 9 April 2013); or Eliot Higgins, the former 'unemployed finance and admin worker' with 'no training in weapons, human rights research or journalism' whose work has been 'taken up by everyone from Amnesty International to the New York Times' (Guardian, 21 March, 2013). ${ }^{7}$ Indeed, in 2012 the Guardian's Comment Is Free blog carried an article detailing how Western journalists had passively reproduced the views of Syrian opposition spokespeople 'selling the idea of military intervention and regime change' (12 July 2012). 
It is also true that critics such as Beeley have managed to get a hearing via 'alternative' websites or Russian media. Yet it seems odd that such relatively modest media resources were seen as so threatening. Perhaps the real worry was that 'respectable' sources were also questioning the simplistic moral narrative about Syria. 'Coverage of the Syrian war will be remembered as one of the most shameful episodes in the history of the American press', said former New York Times correspondent Stephen Kinzer, for example (Boston Globe, 18 February 2016). In Foreign Affairs, American professor Max Abrahms (2017) criticised the 'pro-rebel bias dominant in Western outlets' which were promoting a 'pro-regime change narrative'. Veteran Middle East correspondent Patrick Cockburn (2017) said that 'Western news organisations have almost entirely outsourced their coverage to the rebel side', resulting in 'partisan reporting' which had presented the siege of east Aleppo as 'a battle between good and evil'. Another veteran foreign correspondent, Mary Dejevsky (2018) said she sympathised with 'a dissident strain of thinking....which is at odds with the official consensus', declaring that: 'we reject, or at very least distrust, the dominant official narrative, which appears designed at once to get the UK and other Western countries more directly involved and to thwart or discredit Russia'. In seeking to close down such dissident thought, the Guardian and the Syria Campaign were acting, not as neutral defenders of truth, but as partisan advocates for a particular understanding of the war.

Efforts to delegitimise critique have extended to academia: the morning after the April 2018 US-led airstrikes on Syria, the Times devoted its front page to an attack on academics who had questioned the rationale for the bombing. The headline article 'Apologists for Assad working in British universities' - was accompanied by two-page spread denouncing the academic Working Group on Syria, Propaganda and Media ${ }^{8}$ as 'agents of disinformation and cheerleaders for despotism' who, it strongly implied, should not be employed at British universities. For good measure, the Times also denounced the Working Group as 'Assad's Useful Idiots' in its editorial column (14 April 2018). Though claiming to support 'untrammelled academic inquiry', the Times argued that the scholars associated with the Group were nothing but a 'coterie of Assad apologists' - 'agents of disinformation' whose work was 'a violation of the ethos of academic research'. Researchers affiliated to the Working Group had already described how asking questions about the media presentation of Syria led to them being 'immediately attacked' (Allday 2016), drawing 'abuse or disbelief' via social media (Mason 2018). As this suggests, efforts to discipline dissenters may have had a chilling effect on debate. Generally, however, the effort seems to have backfired. It remains (for now) difficult to close down discussion online, and those whose views were targeted as unacceptable have responded robustly and been defended by others. ${ }^{9}$ Readers may judge for themselves who came out best from these exchanges, but the key point here is that the anti-propaganda 'investigations' presented by the Times, the Guardian and the Syria Campaign were themselves propagandistic.

\section{The White Helmets: a case study in propaganda}

The single most important focus of these debates about propaganda (highlighted in the Times coverage, Solon's article and the Syria Campaign report) was the Syrian volunteer rescue organisation the White Helmets - described by Solon as a 'humanitarian organisation' which had 'exposed....war crimes' and was 'credited with saving thousands of civilians'. Their work, she noted, had received 'positive international recognition', including 'an Oscar-winning Netflix documentary' and 'two Nobel peace prize nominations'. Towards the end of the article, Solon acknowledged 
that there had been 'isolated rogue actors' who had been 'used to discredit the entire group', for example being 'photographed with guns despite marketing themselves as unarmed'. But such 'isolated incidents' were dismissed with a supporting quote from the organisation's head, Raed al-Saleh. These, in other words, were the good guys, the local heroes saving civilians and exposing atrocities. The Syria Campaign advocates and fundraises for the White Helmets; the Guardian carries articles by its leader ${ }^{10}$ and called for the organisation to receive the Nobel Peace Prize. In its 5 October 2016 editorial, the paper argued that awarding the prize was 'the very least the west can do', having 'utterly failed Syrians, by failing to protect them'. In seeking to defend the White Helmets from criticism, the aim was also to defend this view of the conflict, in which Western inaction was the main problem. As the Syria Campaign (2017: 4) explained: 'The international community has done little to stop the bombing of Syrian civilians.... Now governments around the world and social media companies are allowing Russia a free hand to target rescue workers and cast doubt on the evidence of war crimes they are collecting'. From that perspective, any 'counternarrative' looked deeply suspect.

The White Helmets present themselves as a politically-neutral civil defence organisation, made up of ordinary citizens - usually described as 'former bakers, tailors, teachers', and so on - who have saved thousands of lives $(114,431$ at the time of writing in mid-2018). Even if we accept such claims, however, it does seem extraordinary that a search-and-rescue outfit would attract millions of dollars from foreign governments (channelled through third parties), would devote such time and resources to filming their rescue missions, and would campaign in concert with others to influence foreign media and public opinion. Danish peace researcher Jan Oberg (2016) suggests that although the White Helmets are 'treated as uncontroversial in virtually all Western mainstream media', we should be 'cautious with taking information about them at face value'. Oberg does not discount claims that the White Helmets are ordinary Syrians who have volunteered as rescuers, but suggests that it can be understood as a 'dual-purpose organisation' - the other purpose being to act as a propaganda focus for the 'foundations, PR and marketing firms, change organisations, NATO governments and NGOs' who surround it and use it for 'less noble, war-promoting purposes'. As Christina Lin argues, the promotion of the White Helmets is part of an 'increasing US trend of weaponizing human rights' (Asia Times, 24 October 2016).

Indeed, the White Helmets themselves have played an important role in this propaganda effort, since they have consistently filmed themselves and the rebel-held areas in which they operate in such a way as to sustain the West's Manichean narrative about Syria. There has been no comparable effort to support aid and rescue work for victims of rebel attacks, even though, as former Washington Post reporter John Hanrahan (2016a) points out, there has been plenty of evidence that they need it. Discussing a UN report which showed that 'both sides commit massacres', for example, Charles Glass (2015) wrote that civilians suffered 'unimaginable torment at the hands of government and opposition forces alike'. Human Rights Watch has repeatedly documented 'serious abuses committed by opposition forces', saying that they have 'indiscriminately attacked civilians in government-held territory' and have 'killed and maimed hundreds of civilians and destroyed civilian infrastructure in violation of the laws of war'. ${ }^{11}$ Those were presumably unworthy victims, since they did not warrant any Western funding or aid, let alone international PR campaigns and Oscar-winning Netflix documentaries.

As Scott Ritter (2016) notes, there is 'a symbiotic, hand-in-glove relationship between the anti-Assad rhetoric of the ostensibly "neutral and impartial" White Helmets and the policy objectives of their funders'. The Dubai-based company Analysis, 
Research, and Knowledge (ARK) claims credit for establishing the White Helmets, in partnership with 'Syrian local communities and the Turkish NGO AKUT'. ${ }^{12}$ Run by a former British diplomat, ARK's client list is exclusively composed of foreign governments, government agencies and the EU. By the end of 2014, according to the company's website, ARK had 'provided UK, US and Japanese governmentfunded training and equipment to over 400 Syrian volunteers', at which point a separate organisation was established to take over: Mayday Rescue, headed by ARK employee and former British military officer James LeMesurier. According to LeMesurier, Mayday is 'funded by governments which, loosely speaking, are connected to Friends of the Syrian People'. ${ }^{13}$ This is the international diplomatic initiative which, presumably to avoid any Russian or Chinese veto in the UN, meets to coordinate policy with the Syrian opposition, for example agreeing in 2013 to provide 'urgent support to rebels who are fighting President Bashar al-Assad'. ${ }^{14}$ The fact that some of these same governments also provide millions of dollars for civil defence in rebel-held areas may be completely unconnected to their support for armed groups, but even if it were, questions would remain about the final destination of the money. Around half the White Helmets' funding comes via Mayday Rescue according to LeMesurier, $\$ 20-25 \mathrm{~m}$ annually, with the main donors being Britain and other European governments, while a further $\$ 23 \mathrm{~m}$ comes from the US (Independent, 5 October 2016). US funding comes via another contractor, Chemonics, which also handles other projects in Syria for the US government's Office of Transition Initiatives, the costs of which run into the hundreds of millions. As Blumenthal (2016b) points out, Chemonics was accused of wasting tens of millions of dollars from earlier contracts. Given the BBC's investigation of how money for policing ended up in the hands of armed groups, funding for civil defence in rebelcontrolled areas may also require closer scrutiny. ${ }^{15}$

The main significance of the White Helmets, however, is the publicity that surrounds them. As Ritter (2016) comments, 'without this propagandist value the White Helmets would not receive donations on the scale that they currently enjoy'. That propaganda value is mostly added by the Syria Campaign, whose activism seeks to influence Western media by focusing on the civil defence group. It is no wonder that the Syria Campaign sought to undermine Blumenthal by suggesting he was peddling fringe conspiracy theories, since he had exposed them as the "creation of international PR firms' (Blumenthal 2016a). Specifically, Blumenthal highlighted the Campaign's 'connections to Avaaz, a global public relations outfit that played an instrumental role in generating support for a no-fly zone in Libya', and to 'Purpose, another PR firm spun out of Avaaz'. ${ }^{16}$ On its website, the Syria Campaign says it is 'an initiative of the Voices Project', ${ }^{17}$ which is where the various groups intersect: the Voices Project was set up by Purpose and Avaaz co-founder Jeremy Heimans, and includes Purpose co-founder Tim Dixon as a director. ${ }^{18}$ Other Avaaz co-founders include Tom Perriello and Thomas Pravda who, as Hanrahan (2016b) points out, have connections to the US State Department and the British Foreign Office respectively.

None of this might matter were it not for the strikingly similar line on Syria pushed by the White Helmets, the Syria Campaign and Avaaz: all call for a 'no-fly zone'. Avaaz has repeatedly petitioned world leaders to enforce no-fly zones, first in Libya in 2011 and then in Syria, maintaining that it is 'the only decent thing to do' and if 'done well, might not cost a single life'. ${ }^{19}$ The website created for the White Helmets by the Syria Campaign invites visitors to sign up to a statement from the organisation's leader calling on the UN to introduce a no-fly zone. ${ }^{20}$ The Syria Campaign has also argued that 'We must push our leaders to be ready to use force', suggesting that 'European and US forces could strike the Syrian regime airbases and jets' - modelling these 'punitive measures' on what it sees as the successful strategy pursued by NATO in Bosnia in the 1990s. ${ }^{21} \mathrm{~A}$ no-fly zone sounds innocuous - about halting violence 
rather than waging war. Yet the US general who oversaw the implementation of the Libya no-fly zone candidly describes it as 'a violent combat action that results in lots of casualties', while NATO's former supreme allied commander says that 'It is quite frankly an act of war...it's basically to start a war with that country' (quoted in Hanrahan 2016a). This is essentially the reasoning of critics who challenge the propaganda offensive centred on the White Helmets: that what is presented as a campaign for peace, humanitarianism and protection of civilians is actually part of a larger effort at bringing about regime change and escalating war.

\section{Conclusion}

Perhaps critics who challenge the PR campaigns promoting military intervention as a way to protect civilians in Syria, and who question the regime-change policies of Western governments, are unhinged conspiracy theorists, Kremlin apologists or internet trolls. Perhaps funnelling millions of dollars into a war zone and strengthening armed extremists is a certain route to peace and stability. But recent experience, as well as reason, would suggest otherwise. A report by the UK parliamentary Foreign Affairs Committee (2016: 39) said of the 2011 Libyan intervention: 'The possibility that militant extremist groups would attempt to benefit from the rebellion should not have been the preserve of hindsight'. As the Committee also observed:

By the summer of 2011, the limited intervention to protect civilians had drifted into an opportunist policy of regime change....The result was political and economic collapse, inter-militia and inter-tribal warfare, humanitarian and migrant crises, widespread human rights violations, the spread of...regime weapons across the region and the growth of ISIL in North Africa.

(Foreign Affairs Committee 2016: 3)

The failure of Western policy in Syria should have seemed equally predicable - and perhaps would have been so, if journalists were not so preoccupied with rehabilitating the idea of liberal interventionism and giving weight to their 'moral impulse' that they saw active Western interference as inaction.

\section{References}

Abrahms, Max (2017) Syria's Extremist Opposition: How Western Media Have Whitewashed the Rebels' Record, Foreign Affairs, 30 October, www.foreignaffairs.com/articles/middle-east/2017-10-30/syrias-extremist-opposition.

Allday, Louis (2016) Controlling the Narrative on Syria, Monthly Review, 13 December, https://mronline.org/2016/12/13/allday131216-html/.

Blumenthal, Max (2016a) Inside the Shadowy PR Firm That's Lobbying for Regime Change in Syria, AlterNet, 2 October, www.alternet.org/world/inside-shadowy-pr-firmthats-driving-western-opinion-towards-regime-change-syria.

Blumenthal, Max (2016b) How the White Helmets Became International Heroes While Pushing US Military Intervention and Regime Change in Syria, AlterNet, 2 October, www.alternet.org/grayzone-project/how-white-helmets-becameinternational-heroes-while-pushing-us-military. 
Briggs, E. Donald, Walter C. Soderlund and Tom Pierre Najem (2017) Syria, Press Framing, and the Responsibility to Protect. Waterloo, ON: Wilfrid Laurier University Press.

Chandler, David (2000) Western intervention and the disintegration of Yugoslavia, 1989 - 1999, in Philip Hammond and Edward S. Herman (eds.) Degraded Capability: The Media and the Kosovo Crisis. London: Pluto.

Chen, Adrian (2018) A So-Called Expert's Uneasy Dive Into the Trump-Russia Frenzy, The New Yorker, 22 February, www.newyorker.com/tech/elements/a-socalled-experts-uneasy-dive-into-the-trump-russia-frenzy.

Cockburn, Patrick (2017) Who supplies the news?, London Review of Books, 39(3), www.Irb.co.uk/v39/n03/patrick-cockburn/who-supplies-the-news.

Conflict Armament Research (2017) Weapons of the Islamic State. London: Conflict Armament Research Ltd., December, www.conflictarm.com/publications/.

Dejevsky, Mary (2018) Two Views of the Syria Conflict that Seem Never to Meet, Valdai, 1 March, http://valdaiclub.com/a/highlights/two-views-of-the-syria-conflict/.

Foreign Affairs Committee (2016) Libya: Examination of intervention and collapse and the UK's future policy options, 14 September, https://publications. parliament.uk/pa/cm201617/cmselect/cmfaff/119/119.pdf.

Gambill, Gary (2012) Two Cheers for Syrian Islamists, Foreign Policy, 23 August, http://foreignpolicy.com/2012/08/23/two-cheers-for-syrian-islamists/.

Gibbs, David N. (2015) The Srebrenica Precedent, Jacobin, 6 July, www.jacobinmag.com/2015/07/bosnian-war-nato-bombing-dayton-accords/.

Glass, Charles (2015) In the Syrian Deadlands, New York Review of Books, 22 October, www.nybooks.com/articles/2015/10/22/syrian-deadlands/.

Gordon, Philip (2015) It's Time to Rethink Syria, Politico, 25 September, www.politico.com/magazine/story/2015/09/its-time-to-rethink-syria-213184.

Hallin, D. (1986) The 'Uncensored War': The Media and Vietnam. Oxford: Oxford University Press.

Hanrahan, John (2016a) As in Libya, Avaaz Campaigns for Syria No-Fly Zone That Even Top Generals Oppose, Common Dreams, 11 April, www.commondreams.org/views/2016/04/11/libya-avaaz-campaigns-syria-no-flyzone-even-top-generals-oppose.

Hanrahan, John (2016b) Avaaz Ignores Libya Lessons in Advocating for Syria No-Fly Zone, Expose Facts, 13 April https://exposefacts.org/avaaz-ignores-libya-lessons-inadvocating-for-syria-no-fly-zone/.

Higgins, Patrick (2015) The War on Syria, Jacobin, 27 August, www.jacobinmag.com/2015/08/syria-civil-war-nato-military-intervention/.

Hume, Mick (1997) Whose War is it Anyway? London: Informinc. 
Lister, Charles (2015) Why Assad Is Losing, Foreign Policy, 5 May, https://foreignpolicy.com/2015/05/05/why-assad-is-losing-syria-islamists-saudi/.

Lund, Aron (2013) The Free Syrian Army Doesn't Exist, Syria Comment, 16 March, www.joshualandis.com/blog/the-free-syrian-army-doesnt-exist/.

Lynch, Marc (2012) The 'Arm the FSA' Bandwagon, Foreign Policy, 9 February, http://foreignpolicy.com/2012/02/09/the-arm-the-fsa-bandwagon/.

Mason, Jake (2018) Researching Politically Sensitive Topics, Medium, 26 February, https://medium.com/@jakekmason/researching-politically-sensitive-topics-

$7 \mathrm{cdb00f7c27e.}$

Matta, Nada (2015) What Happened to the Arab Spring? An interview with Gilbert Achcar, Jacobin, 17 December, www.jacobinmag.com/2015/12/achchar-arab-springtunisia-egypt-isis-isil-assad-syria-revolution.

Milojevich, Jovan and Peter Beattie (2018) The Pull of Humanitarian Interventionism: Examining the Effects of Media Frames and Political Values on People's Choice of Resolution, International Journal of Communication, 12: 831-55.

Oberg, Jan (2016) Just how grey are the White Helmets and their backers? (TFF PressInfo \#392), TFF Associates \& Themes Blog, 1 November, http://blog.transnational.org/2016/11/tff-pressinfo-392-just-how-grey-are-the-whitehelmets-and-their-backers/.

Ritter, Scott (2016) The 'White Helmets' and the Inherent Contradiction of America's Syria Policy, Truthdig, 5 October, https://www.truthdig.com/articles/the-whitehelmets-and-the-inherent-contradiction-of-americas-syria-policy/.

Solon, Olivia (2017) How Syria's White Helmets became victims of an online propaganda machine, Guardian, 18 December, www.theguardian.com/world/2017/dec/18/syria-white-helmets-conspiracy-theories.

Syria Campaign (2017) Killing the Truth: How Russia is fuelling a disinformation campaign to cover up war crimes in Syria, 20 December, https://diary.thesyriacampaign.org/killing-the-truth/.

\footnotetext{
${ }^{1}$ For example, Welcome to Aleppo (www.ryot.org/blog/stories/welcome-to-aleppo)
} and Endgame: Syria (http://gamethenews.net/index.php/endgame-syria/).

${ }^{2}$ MSNBC, 12 April 2018: https://www.msnbc.com/morning-joe/watch/should-the-usbe-part-of-solution-in-syria-or-leave-1209166915804.

${ }^{3}$ See www.youtube.com/watch?v=NMInxu1zrNk.

${ }^{4}$ Panorama: Jihadis You Pay For, 4 December 2017, www.bbc.co.uk/programmes/b09jofql.

${ }^{5}$ Lucas Scott, Who are Syria's White Helmets, and why are they so controversial?, The Conversation, 7 October 2016, https://theconversation.com/who-are-syriaswhite-helmets-and-why-are-they-so-controversial-66580; Eliot Higgins, There's No Such Thing as a Good Fake, Bellingcat, 30 November 2016, www.bellingcat.com/resources/articles/2016/11/30/theres-no-thing-good-fake- 
publicity-stunts-go-wrong/. Solon's description of how a misleading counter-narrative was constructed could almost describe her own methodology: 'The same handful of people are quoted as "experts" in articles that are repackaged and interlinked to create a body of content whose conspiracy claims gain a semblance of legitimacy'.

${ }^{6}$ Syria Gay Girl in Damascus blog a hoax by US man, BBC News, 13 June, www.bbc.co.uk/news/world-middle-east-13744980.

${ }^{7}$ Higgins's description of Beeley as 'a person plucked from obscurity by Russian state media', unwittingly presents her as his alter-ego (Newsweek, 13 February 2018).

${ }^{8}$ See: http://syriapropagandamedia.org/about. Two authors of this chapter are affiliated with the Working Group. Similar criticisms had already been made by the Guardian's former Middle East editor, Brian Whitaker, who described the Working Group as 'more like a propaganda exercise than a serious academic project' (Brian Whitaker The Syrian conflict's anti-propaganda propagandists, Medium, 26 February 2018, https://medium.com/@Brian_Whit/the-syrian-conflicts-anti-propagandapropagandists-ebb3e5752e16).

${ }^{9}$ See for example: Eva Bartlett, How the Mainstream Media Whitewashed AI-Qaeda and the White Helmets in Syria, In Gaza, 6 January 2018,

https://ingaza.wordpress.com/2018/01/06/how-the-mainstream-media-whitewashedal-qaeda-and-the-white-helmets-in-syria/; Tim Hayward, The Guardian, White Helmets, and Silenced Comment, 12 January 2018, https://timhayward.wordpress.com/2018/01/12/the-guardian-white-helmets-andsilenced-comment/; Jonathan Cook The authoritarians who silence Syria questions, 27 February 2018, www.jonathan-cook.net/blog/2018-02-27/authoritarians-syriaquestions/.

${ }^{10}$ See: www.theguardian.com/profile/raed-al-saleh.

${ }^{11}$ See HRW's reports at www.hrw.org/report/2013/10/10/you-can-still-see-theirblood/executions-indiscriminate-shootings-and-hostage (2013), and www.hrw.org/news/2015/03/22/syria-rebels-car-bombs-rockets-kill-civilians (2015).

${ }^{12}$ See http://arkgroupdmcc.com/casestudies/training/. ARK's client list is at http://arkgroupdmcc.com/about/clients/.

13 Jemma Dempsey, The most dangerous job in the world, Hemmingfire, 17 November 2015, www.hemmingfire.com/news/fullstory.php/aid/2610/The_most_dangerous_job_in_the _world_96_Syria_92s_White_Helmets.html.

${ }^{14}$ Friends of Syria group agree urgent support for rebels, BBC News, 22 June 2013, www.bbc.co.uk/news/av/world-middle-east-23016225/friends-of-syria-group-agreeurgent-support-for-rebels.

${ }^{15}$ In December 2015 the UK government reported spending $£ 15 \mathrm{~m}$ on the White Helmets, as part of a $£ 100 \mathrm{~m}$ 'non-humanitarian aid' package designed to help the opposition prepare for the 'post-Assad era'; and a further $£ 5.3 \mathrm{~m}$ for media activists, including 'civil society groups and the likes of the White Helmets' (www.gov.uk/government/uploads/system/uploads/attachment_data/file/481277/Syri a_UK_Non-Humanitarian_Support_-_Public_Document.pdf). 
${ }^{16}$ The Syria Campaign responded that while Purpose helped with 'early set up', from 'December 2013, four months before its public launch' it was 'an independent legal organisation'

(https://docs.google.com/document/d/1pxyMCGNvslgYmZOUmzdu5Y1xX2ccJLI4X9 UGxK0uY1U/edit). Yet in November 2014 Purpose co-founder Tim Dixon presented the Syria Campaign as a shining example of his company's work, taking credit for achieving 'significant breakthroughs on public engagement, media narratives and funding' for the White Helmets

(www.bond.org.uk/data/files/Bond_conference_2014/campaign_showcase.pdf).

${ }^{17}$ https://thesyriacampaign.org/terms/.

${ }^{18}$ See the Companies House listing at https://beta.companieshouse.gov.uk/company/08825761.

${ }^{19}$ See https://secure.avaaz.org/campaign/en/protect_syrian_civilians_loc/?.

${ }^{20}$ www.whitehelmets.org/en.

${ }^{21}$ See https://act.thesyriacampaign.org/letter/save-ghouta/?. 